\title{
Evaluation of Rambouillet, Polypay, and Romanov-White Dorper $\times$ Rambouillet ewes mated to terminal sires in an extensive rangeland production system: Lamb production ${ }^{1,2}$
}

\author{
D. R. Notter, $*^{3}$ M. R. Mousel, $\dagger^{4}$ G. S. Lewis, $\dagger^{5}$ K. A. Leymaster, $\uparrow^{5}$ and J. B. Taylor $\dagger$ \\ *Department of Animal and Poultry Sciences, Virginia Tech, Blacksburg 24061; \\ †USDA, ARS, Range Sheep Production Efficiency Research Unit, U.S. Sheep Experiment Station, \\ Dubois, ID 83423; and ¥USDA, ARS, Roman L. Hurska U.S. Meat Animal Research Center, Clay Center, NE 68933
}

\begin{abstract}
Ewe productivity (i.e., total number or weight of lambs weaned per breeding ewe) is a key indicator of lamb production efficiency. This study compared various measures of ewe productivity and ewe and lamb performance among ewes of 3 breed types mated to rams of 4 terminal-sire breed types in an extensive rangeland production system. Purebred Rambouillet ( $n=212$ ), purebred Polypay $(n=236)$, and crossbred Romanov-White Dorper $\times$ Rambouillet (RW-RA; $n=231$ ) ewes were produced from locally adapted Polypay and Rambouillet ewes and then annually mated to Columbia, Suffolk, Columbia $\times$ Suffolk, or Suffolk $\times$ Columbia sires for up to $4 \mathrm{yr}$, beginning at $1 \mathrm{yr}$ of age. The cumulative number and weight of lambs weaned through 4 yr were greater for RW-RA (5.9 lambs and $153 \mathrm{~kg}$, respectively) and Polypay ewes (4.9 lambs and 123 $\mathrm{kg}$, respectively) than for Rambouillet ewes (2.9 lambs and $99 \mathrm{~kg}$, respectively) and also were greater for RW-RA ewes than for Polypay ewes (all $P<$ $0.001)$. Greater productivity of RW-RA and Polypay ewes, compared with Rambouillet ewes, was driven by greater lambing rates (ewes lambing per ewe
\end{abstract}

exposed) as ewe lambs (87 and 77 vs. 31\%, respectively; $P<0.001)$ and greater $(P<0.001)$ litter sizes as ewe lambs $(1.3,1.3$, and 1.0 , respectively) and adult ewes $(2.1,2.0$, and 1.6 , respectively). The RW-RA ewes also had greater longevity $(P<0.01)$ and cumulative lambing rates $(P<0.001)$ than Polypay and Rambouillet ewes. Lamb BW at birth and weaning in adult ewes favored less-prolific Rambouillet ewes $(P<0.001)$, but after adjustment for type of birth and rearing and weaning age, differences in weaning BW among ewe breed types were small and not significant $(P=0.08)$. Effects of sire breed type on measures of cumulative ewe productivity were not significant $(P>0.74)$, but Suffolk-sired lambs had the heaviest adjusted birth weights $(P=0.01)$ and Columbia-sired lambs tended to have the lightest adjusted weaning weights $(P=0.12)$. Combined effects of heterosis and additive breed effects were associated with greater lambing rates in ewe lambs, larger litters at all ages, and substantially greater number and weight of lambs weaned for Polypay and RW-RA ewes than for Rambouillet ewes.

Key words: breeds, ewe productivity, growth, lambing rate, prolificacy, sheep

\footnotetext{
${ }^{1}$ Mention of trade names or commercial products in this publication is solely for the purpose of providing specific information and does not imply recommendation or endorsement by the U.S. Department of Agriculture. The USDA is an equal opportunity provider and employer.

${ }^{2}$ The authors wish to thank M. Williams, N. Pierce, and the U.S. Sheep Experiment Station technical staff for animal procedures and data collection.
}

\footnotetext{
${ }^{3}$ Corresponding author: drnotter@vt.edu

${ }^{4}$ Present address: USDA, ARS, Animal Disease Research Unit, 3003 ADBF, Washington State University, Pullman 99164 ${ }^{5}$ Retired.

Received April 10, 2017.

Accepted June 21, 2017.
} 


\section{INTRODUCTION}

Ewe productivity (i.e., total number or weight of lambs weaned per breeding ewe) is a key indicator of lamb production efficiency (Snowder and Fogarty, 2009). On an individual-ewe basis, ewe productivity measures differences among ewes in production efficiency and adaptation to the production system. Measures of ewe productivity also set a baseline for profitability in sheep production enterprises because differences in growth and carcass value generally cannot overcome deficits in number of lambs marketed. On an industry or ranch level, ewe productivity is an indicator of efficiency of conversion of land and feed resources into a marketable product.

Ewe productivity has been studied at the U.S. Sheep Experiment Station (USSES) in Dubois, ID, for over $100 \mathrm{yr}$ (Lupton, 2008). The Polypay breed was developed there by crossing Rambouillet, Targhee, Dorset, and Finnsheep breeds to retain the rangeland adaptation, flocking instinct, and wool production and quality of Rambouillet and Targhee; improve prolificacy by introducing 25\% Finnsheep breeding; and use the Dorset to enhance milk production and reduce seasonal breeding (Hulet et al., 1984). The Polypay has been productive and well adapted to both rangeland and intensive production systems but has not been compared with range breeds such as the Rambouillet in terminal-sire crossbreeding under rangeland conditions. In addition, evidence has accumulated that the Romanov is superior to the Finnsheep as a prolific breed (Thomas, 2010), and there is potential for hair sheep composite breeds such as the Katahdin and Dorper to increase ewe productivity, lamb survival, and other "easy-care" sheep characteristics (Notter, 1999; Alemseged and Hacker, 2014). This study therefore was designed to compare lamb performance and ewe productivity of Rambouillet, Polypay, and Romanov-White Dorper $\times$ Rambouillet $(\mathbf{R W}$-RA) ewes mated to terminal sires under extensive rangeland conditions.

\section{MATERIALS AND METHODS}

The USSES Institutional Animal Care and Use Committee (IACUC) approved all husbandry practices and experimental procedures used in this study (IACUC numbers 0905 and 1105).

\section{Animals and Management}

Ewe lambs were produced in 2009, 2010, and 2011 by mating USSES Rambouillet ewes to 1 of 7 Rambouillet rams or 1 of 7 Romanov $\times$ White Dorper rams and mating USSES Polypay ewes to 1 of 7 Polypay rams in single-sire mating pens. Ewes were 2 to 8 yr old at lambing. Most rams were used for only $1 \mathrm{yr}$, but 1 Polypay ram was used in a second year. Twenty Polypay, 21 Rambouillet, and 21 Romanov $\times$ White Dorper sires were represented in the study. Romanov $\times$ White Dorper rams were obtained from the U.S. Meat Animal Research Center (USMARC) where they were produced to contribute to an easy-care composite flock for use in pasture-lambing production systems. Selection at the USMARC favored ram lambs that were polled, resistant to scrapie, and naturally raised as twins or triplets and that shed white fleeces. Of the 21 crossbred rams used at the USSES, 15 had previously produced progeny at the USMARC. Polypay rams were sampled from 18 industry flocks in 10 states between Colorado and Ohio. Rambouillet rams were sampled from 20 industry flocks in 13 states from Idaho to Ohio. One Rambouillet and 1 Polypay ram were sampled from USSES flocks and produced daughters in 2009 and 2010, respectively. Ram suppliers were asked to provide 1- to 2-yr-old rams that they considered to be representative of the breed and of their flock, had a genotype of RR at prion protein locus 171, and tested negative for Brucella ovis.

A total of 679 ewe lambs (212 Rambouillet, 236 Polypay, and 231 RW-RA), representing approximately $75 \%$ of available weaned ewe lambs, were retained for evaluation. Ewe lambs were excluded from the study if they had physical malformations, exhibited serious departures from breed type, or were considered too small to potentially conceive. Ewe lambs were exposed to rams for the first time at 7 to $8 \mathrm{mo}$ of age and retained for up to 4 yr. Ewes were removed from the study only if they died or became functionally unsound. In each year, ewe lambs and adult ewes were separately mated to Suffolk, Columbia, Suffolk $\times$ Columbia, or Columbia $\times$ Suffolk rams in 1 of 4 mating pens. The terminal-sire breed type was randomly assigned to each ewe lamb and maintained throughout the study, and the ram breed type was randomly assigned to mating pens within each year. Each mating pen contained 2 to 4 rams, depending on the year, number of ewes to be serviced, and availability of rams. Eighteen to 21 rams per breed type were used in the study, with 2 to 5 rams per breed used in consecutive years. The number of rams in each mating pen was constant across ewe breed types within a mating year and ewe age class. Rams were produced by mating Suffolk and Columbia ewes and rams from USSES flocks. The Columbia and Suffolk sires used in USSES flocks in 2006 through 2008 were described by Leeds et al. (2012). Selection in USSES terminalsire breeds was based mainly on the individual lamb's growth through weaning and dam productivity (number of lambs born and reared and weight of lamb weaned) and was balanced to represent all sires per breed type that produced lambs in a given year. Individual terminal 
sires used in this project generally came from the upper $25 \%$ of those available for weaning weight.

In both generations, ewes were exposed to rams in feedlot pens or sagebrush steppe pastures for $21 \mathrm{~d}$ beginning in mid October. At the end of the primary mating period, adult ewes were combined into a single group, moved to shrub-dominated winter range, and exposed to Suffolk cleanup rams for an additional $21 \mathrm{~d}$. Ewe lambs remained in their original mating pens until the end of mating in late November or early December, when they were moved to a feedlot until lambing. Adult ewes grazed on winter range until mid to late January and then were moved to a feedlot until lambing. Ewes were shorn and vaccinated against clostridial diseases in mid February and lambed in feedlot pens in March and April. Ewes and their lambs were moved indoors within $30 \mathrm{~min}$ after lambing and confined for approximately 48 $\mathrm{h}$ in single-ewe bonding pens. Lambs were tagged and weighed within $24 \mathrm{~h}$ after birth. In Generation 1, all male RW-RA lambs were castrated within $24 \mathrm{~h}$ after birth, but approximately $50 \%$ of male Rambouillet and Polypay lambs were left intact for evaluation as potential breeding rams. Ewes whose male progeny were to be castrated were identified before lambing based on their previous ewe productivity (weight of lamb weaned per ewe exposed; Snowder and Fogarty, 2009). In Generation 2, all male lambs were castrated within $24 \mathrm{~h}$ after birth. Ewes and lambs were then returned to feedlots for approximately $1 \mathrm{mo}$. While housed in feedlots (i.e., during breeding and early lactation), ewes were fed daily a total mixed ration that was formulated to meet or slightly exceed nutrient requirements with respect to the production stage and environmental conditions.

Most ewes at the USSES that produce more than 2 live lambs have their litters reduced to 2 lambs. Surplus lambs were normally fostered to ewes with smaller litters or removed (orphaned) and sold within $3 \mathrm{~d}$ of birth. However, for this study, lamb removal was restricted to ewes with severe functional problems (e.g., mastitis, no milk, ruptured prepubic tendon, extreme lameness, etc.) to assess the full impact of increasing litter size and the capacity of Polypay and RW-RA ewes to rear their live-born litter. Only 3.6 and $2.0 \%$ of lambs born in Generations 1 and 2, respectively, were fostered or orphaned. Over $25 \%$ of these lambs were from quadruplet litters, which were frequently reduced to 2 lambs.

Lambs were weighed in late April at a mean age of 33 $\mathrm{d}$ (range $=7$ to $51 \mathrm{~d}$ ). In 2009 and 2010, ewes and lambs then grazed sagebrush steppe from late April through early July and subalpine forest from early July until weaning in early August at a mean lamb age of 123 d. In 2011 through 2015, ewes and lambs grazed sagebrush steppe from late April until weaning in July at a mean age of $106 \mathrm{~d}$. In all years, ewes and lambs were randomly as- signed at lambing to 1 of 2 groups ("weaning bands") for summer grazing and separately herded on broadly comparable, but physically separated, grazing areas.

From 2012 through 2015, a single ultrasound image from the left side between the 12th and 13th ribs (Leeds et al., 2008) was captured at weaning from Generation 2 wether lambs. Fat depth at the middle of the loin muscle and loin muscle area were measured (Leeds et al., 2008).

\section{Statistical Analysis}

Generation 1. Outcomes for Generation 1 matings included lambing rate (ewes lambing per ewe present at lambing), litter size (including both live and stillborn lambs), lamb survival (to $3 \mathrm{~d}$ of age and to weaning), and lamb BW at birth, in spring, and at weaning. Records from ewes that did not survive until the start of lambing or that died during lambing without information on their pregnancy status were excluded from the data. Ewes that produced lambs sired by clean-up rams were coded as open, and their litter size and lamb performance records were excluded from the data. Records for ewes that produced lambs that were coded as premature based on their weight and apparent maturity at birth were included in analyses of lambing rate, litter size, and lamb survival. Birth weights, however, were excluded from the data for these lambs and for other lambs with birth weights of $2 \mathrm{~kg}$ or less. None of these lambs survived to produce postnatal weight records. Productivity of Generation 1 dams was further summarized by considering Julian lambing dates, number of live lambs at $3 \mathrm{~d}$ per ewe lambing, and number and weights of lambs weaned per ewe lambing and per ewe exposed.

Models for lambing rate, litter size, and measures of ewe productivity included fixed effects of lambing year, mating type (Rambouillet, Polypay, or RW-RA), ewe age (categorized to compare 2-, 3-, 4-, 5-, and 6through 8 -yr-old ewes), and lambing year $\times$ mating type and ewe age $\times$ mating type interactions. The model also included random effects of mating pen (i.e., service sire) nested within lambing year and mating type, sire of the dam nested within the dam breed, individual dam nested within the sire of the dam, and residual error. No 2-yr-old ewes were present in 2010, which precluded estimation of least squares means for ewe age effects when lambing year $\times$ ewe age interaction was included in the model. This interaction was not significant $(P \geq$ 0.14 ) and was excluded from the final model. Lambing rate and litter size were analyzed using the GLIMMIX procedure in SAS (SAS Inst., Inc., Cary, NC). Lambing rate was modeled as a binomial variable, and least squares means and SE were back-transformed to the original scale. Litter size was modeled as an ordered multinomial variable with 4 classes. This option did not 
allow estimation of least squares means on the original scale, so model effects were tested using the GLIMMIX procedure, but least squares means and SE were estimated using the Mixed Model procedure in SAS with the same model. Other measures of ewe productivity were analyzed using the mixed model procedure.

Lamb birth weight, spring weight, and weaning BW and weaning age were analyzed using the Mixed Model procedure, and lamb survival was analyzed as a binomial variable using the GLIMMIX procedure. Models for lamb traits included fixed and random effects used in models of ewe productivity plus a fixed effect of lamb sex. Frequencies of ram and wether lambs differed among lamb breed groups, and spring weights and weaning weights for intact male lambs, therefore, were adjusted to a wether lamb equivalent before analysis using a multiplicative adjustment factor of 0.94 from the National Sheep Improvement Program (NSIP; Bradford, 2003). The weaning weight analysis also included effects of weaning band and birth year $\times$ weaning band interaction. A small number of lambs (33 lambs, 1.8\% of the lambs weaned) were held in a "hospital" band for monitoring of health problems or injury to the ewe or lamb and were excluded from the weaning weight analysis but included in analyses of lamb survival and ewe productivity. Year $\times$ dam age interaction was not significant $(P \geq 0.14)$ and was excluded from these models to allow estimation of least squares means for dam age effects.

Initial models did not include effects of litter size on lamb birth weight and survival or effects of number of lambs born and reared or age at weighing on subsequent lamb weights. Therefore, these models described realized lamb performance for dam breed types that differed in average prolificacy. However, an effect of litter size subsequently was added to models for birth weight and lamb survival. The continuous effect of age at weighing, fixed effect of number of lambs born and reared, and interactions of type of birth and rearing with ewe breed type and sire breed type nested within ewe breed type were likewise added to the model for lamb BW in spring and at weaning. Type of birth and rearing were coded as 11, 21, 22, 31, 32 , and 33, which encompassed birth-rearing classes that were present at reasonable frequencies (i.e., $n \geq 65$, corresponding to $\geq 3.6 \%$ of lambs weaned). Quadruplet lambs were rare (32 lambs), distributed among various birth-rearing classes (i.e., 41, 42, and 43), and produced only by Polypay ewes. Weaning weight records of quadruplet lambs were therefore adjusted to a triplet-lamb equivalent (i.e., 41 to 31 , etc.) before analysis using NSIP multiplicative adjustment factors derived for Polypay sheep (D. R. Notter, Virginia Tech, Blacksburg, personal communication).
Generation 2. Outcomes for Generation 2 included all traits recorded in Generation 1. In addition, ewe survival information was tabulated to determine ewe longevity and ewe productivity was assessed as the number and total weight of lambs weaned per ewe exposed, per ewe lambing, and per ewe lamb entering the study, accumulated over the 4 lambing opportunities. Measurements of annual ewe productivity per ewe exposed or per ewe lambing were based on ewes present at lambing. Based on observed differences among sire breed types (discussed below), lambs produced by clean-up sires were included in Generation 2 analyses of ewe productivity but not individual lamb performance. Generation 2 data also included ultrasonic measurements of lamb fat depth and loin muscle area at weaning.

Models used to analyze measures of ewe performance and productivity in Generation 2 included fixed effects of ewe age class (ewe lambs vs. adult ewes); ewe birth year, dam age, and their interaction (all nested within ewe age class and, therefore, incorporating effects of lambing year); ewe breed type; lamb sire breed type; and the remaining 2-way interactions. Random effects in these analyses included the sire of the ewe (nested within ewe sire breed type and birth year), individual ewe (nested within ewe birth year, ewe sire, and lamb sire breed type), and lamb sire breed type $\times$ ewe age class $\times$ lambing year interaction. The latter interaction included variation among pens of lamb sires of the same breed type and provided a test term for effects of lamb sire breed type. The model for analysis of ewe longevity (expressed as the total number of matings or lambings) and cumulative ewe productivity through 4 lambing opportunities was simplified to include only fixed effects of ewe birth year, ewe breed type, lamb sire breed type, and all 2-way interactions and a random effect of sire of the ewe (nested within ewe breed type and birth year).

Models for analysis of individual lamb performance included effects used in models of ewe performance plus a fixed effect of lamb sex (ewe vs. wether) and a random effect of lambing year nested within ewe (i.e., litter). Models for lamb weaning weight and scanning measurements also included fixed effects of weaning band and interactions of weaning band with ewe age class, ewe breed type, and ewe age nested within ewe age class. As in Generation 1, lamb birth weight and survival were analyzed with and without inclusion of effects of litter size in the model and lamb weaning weight was analyzed with and without inclusion of a continuous effect of age at weighing and a fixed effect of number of lambs born and reared in the model. Ultrasonic measurements of fat depth and loin muscle area were analyzed only for progeny of adult (2- through 4-yr-old) ewes because progeny of ewe lambs were scanned in only $1 \mathrm{yr}$ and were analyzed with and without adjustment for BW 
Table 1. Least squares means and SE for performance of ewes and lambs in Generation 1 straightbred Rambouillet $(\mathrm{RA} \times \mathrm{RA})$ and Polypay $(\mathrm{PP} \times \mathrm{PP})$ matings and crosses of Romanov $\times$ White Dorper rams with Rambouillet ewes $(\mathrm{RW} \times \mathrm{RA})$

\begin{tabular}{|c|c|c|c|c|c|}
\hline \multirow[b]{2}{*}{ Measurement } & \multirow{2}{*}{$\begin{array}{c}\text { No. of } \\
\text { observations }\end{array}$} & \multicolumn{3}{|c|}{ Mating type } & \multirow[b]{2}{*}{ SE } \\
\hline & & $\mathrm{RA} \times \mathrm{RA}$ & $\mathrm{PP} \times \mathrm{PP}$ & $\mathrm{RW} \times \mathrm{RA}$ & \\
\hline Lambing rate, $\%$ & $63^{4}$ & $89^{\mathrm{a}}$ & $97^{\mathrm{b}}$ & $92^{\mathrm{ab}}$ & 2 \\
\hline Litter size & $1,206^{6}$ & $1.95^{\mathrm{a}}$ & $2.36^{\mathrm{b}}$ & $1.93^{\mathrm{a}}$ & 0.04 \\
\hline Lambing date, Julian day & $1,203^{6}$ & $99.7^{\mathrm{a}}$ & $95.9^{\mathrm{b}}$ & $97.4^{\mathrm{c}}$ & 0.4 \\
\hline Birth weight, ${ }^{1} \mathrm{~kg}$ & $2,512^{7}$ & $4.90^{\mathrm{a}}$ & $4.13^{\mathrm{b}}$ & $4.49^{\mathrm{c}}$ & 0.05 \\
\hline Adjusted birth weight, ${ }^{2} \mathrm{~kg}$ & $2,512^{7}$ & $4.59^{\mathrm{a}}$ & $4.16^{\mathrm{b}}$ & $4.19^{\mathrm{b}}$ & 0.06 \\
\hline Lamb survival to $3 \mathrm{~d},{ }^{1} \%$ & $2,529^{7}$ & $93^{\mathrm{a}}$ & $87^{\mathrm{b}}$ & $94^{\mathrm{a}}$ & 1 \\
\hline Adjusted lamb survival to $3 \mathrm{~d},{ }^{2} \%$ & $2,529^{7}$ & 90 & 86 & 89 & 2 \\
\hline Live lambs at $3 \mathrm{~d}$ per ewe lambing & $1,206^{6}$ & $1.75^{\mathrm{a}}$ & $2.01^{\mathrm{b}}$ & $1.79^{\mathrm{a}}$ & 0.04 \\
\hline Spring weight, ${ }^{1} \mathrm{~kg}$ & $1,972^{7}$ & $10.2^{\mathrm{a}}$ & $9.4^{b}$ & $10.1^{\mathrm{a}}$ & 0.1 \\
\hline Adjusted spring weight, ${ }^{3} \mathrm{~kg}$ & $1,972^{7}$ & 9.7 & 9.8 & 10.0 & 0.2 \\
\hline Weaning rate, ${ }^{1} \%$ & $2,529^{7}$ & $72^{\mathrm{a}}$ & $67^{\mathrm{a}}$ & $86^{\mathrm{b}}$ & 2 \\
\hline Adjusted weaning rate, ${ }^{2} \%$ & $2,529^{7}$ & 71 & 70 & 82 & 4 \\
\hline Weaning age, $\mathrm{d}$ & $1,811^{7}$ & $113.9^{\mathrm{a}}$ & $117.3^{\mathrm{b}}$ & $116.2^{\mathrm{b}}$ & 0.4 \\
\hline Weaning weight, ${ }^{1} \mathrm{~kg}$ & $1,811^{7}$ & 30.6 & 31.3 & 31.1 & 0.3 \\
\hline Adjusted weaning weight, ${ }^{3} \mathrm{~kg}$ & $1,811^{7}$ & 30.8 & 31.6 & 31.3 & 0.4 \\
\hline No. weaned per ewe lambing & $1,206^{6}$ & $1.38^{\mathrm{a}}$ & $1.55^{\mathrm{b}}$ & $1.61^{\mathrm{b}}$ & 0.04 \\
\hline Weight weaned per ewe lambing, $\mathrm{kg}$ & $1,206^{6}$ & $42.7^{\mathrm{a}}$ & $49.3^{\mathrm{b}}$ & $50.0^{\mathrm{b}}$ & 1.1 \\
\hline No. weaned per ewe exposed & $1,267^{5}$ & $1.24^{\mathrm{a}}$ & $1.54^{\mathrm{b}}$ & $1.56^{\mathrm{b}}$ & 0.04 \\
\hline Weight weaned per ewe exposed, kg & $1,267^{5}$ & $38.3^{\mathrm{a}}$ & $49.1^{\mathrm{b}}$ & $48.4^{\mathrm{b}}$ & 1.4 \\
\hline
\end{tabular}

${ }^{\mathrm{a}-\mathrm{c}}$ Mating group means within a row with different superscripts differ $(P<0.05)$ using the Tukey-Kramer mean separation procedure.

${ }^{1}$ Adjusted for effects of ewe age and lamb sex.

${ }^{2}$ Adjusted for effects of ewe age, lamb sex, and litter size.

${ }^{3}$ Adjusted for effects of ewe age, lamb sex, type of birth and rearing, and lamb age at weighing.

${ }^{4}$ Experimental units for these analyses were mating pens.

${ }^{5}$ Experimental units for these analyses were individual matings.

${ }^{6}$ Experimental units for these analyses were individual lambings.

${ }^{7}$ Experimental units for these analyses were individual lambs.

at scanning. Adjustment of scanning traits $(Y)$ for BW was achieved by logarithmic transformation of scanning traits and BW and fitting of an allometric relationship, $Y=\alpha(\mathrm{BW})^{\beta}$ (Notter et al., 2012).

\section{RESULTS}

\section{Generation 1}

Many Generation 1 dams had only 1 mating record, and removal of random effects of breeding pen $(P=0.40$ in the mixed model analysis) and dam (which converged to 0 in the mixed model analysis) was required to achieve convergence of the solution vector in the GLIMMIX analysis of lambing rate. Removal of dam effects from the GLIMMIX litter size analysis was likewise required to achieve convergence, even though dam effects were significant $(P<0.001)$ in the mixed model analysis. These adjusted models revealed (Table 1) that lambing rates in Generation 1 were greater $(P<0.01)$ for Polypay ewes $(97 \pm 2 \%)$ than for Rambouillet ewes $(91 \pm 1 \%)$ and that Polypay ewes had larger $(P<0.001)$ litters $(2.36 \pm 0.04$ lambs $)$ than Rambouillet ewes (1.94 \pm 0.03 lambs). Rambouillet ewes bred to Rambouillet or Romanov-White Dorper rams did not differ in lambing rate $(P=0.17)$ or litter size $(P=0.62)$. Ewe age classes did not differ in lambing rate $(P=0.46)$ but differed in litter size $(P<0.001$; Fig. 1). Ewe age $\times$ ewe breed interaction was not significant for lambing rate $(P>0.29)$ or litter size $(P>0.49)$.

When lamb birth weights were adjusted for effects of lamb sex and ewe age class, but not litter size, birth weights were greater for Rambouillet lambs $(4.90 \pm 0.05 \mathrm{~kg})$ than for RW-RA $(4.49 \pm 0.05 \mathrm{~kg})$ or Polypay ( $4.13 \pm 0.05 \mathrm{~kg})$ lambs and greater for RW-RA lambs than for Polypay lambs (all $P<0.001$; Table 1). However, including effects of litter size in the model reduced differences in mean birth weighs between RWRA and Polypay lambs to only $0.03 \mathrm{~kg}$, indicating that observed differences between Polypay and RW-RA lambs largely reflected differences in litter size. Birth weights declined as litter size increased $(5.45 \pm 0.06$, $4.61 \pm 0.04,3.88 \pm 0.04$, and $3.31 \pm 0.12 \mathrm{~kg}$ for litters of 1,2, 3, and 4, respectively; all differences $P<0.001$ ). 

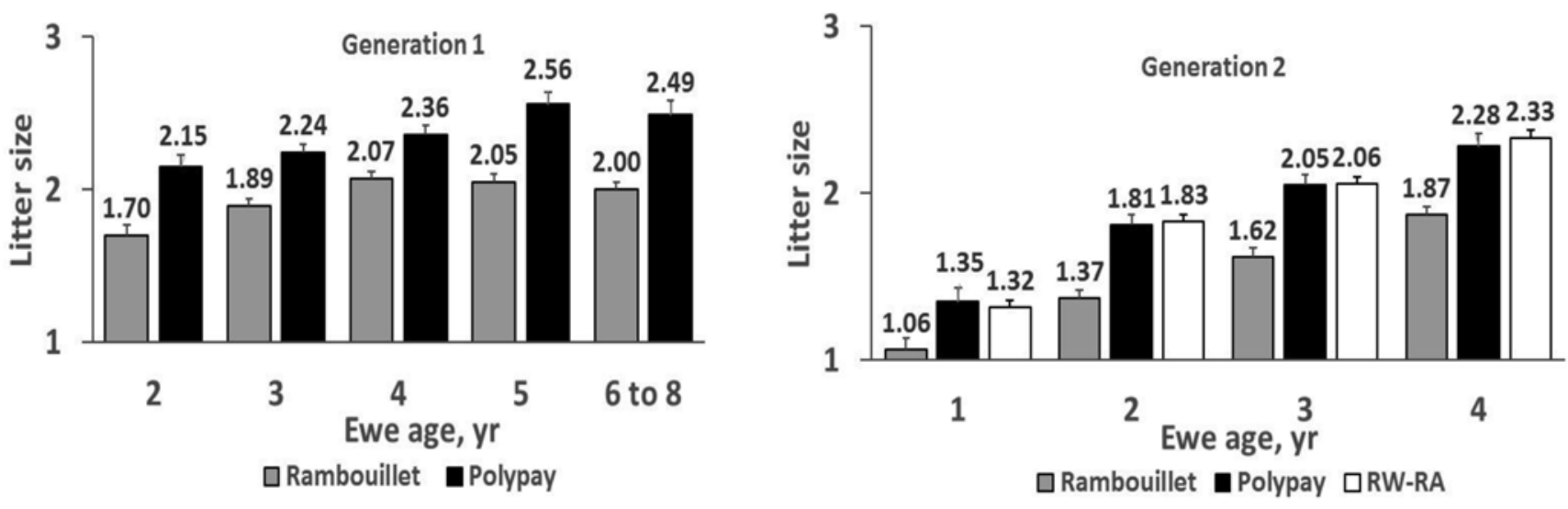

Figure 1. Average litter size (number of lambs born per ewe lambing) by ewe age for Rambouillet and Polypay ewes in Generations 1 and Rambouillet, Polypay, and Romanov-White Dorper $\times$ Rambouillet (RW-RA) ewes in Generation 2.

Birth weights were lightest $(P<0.01)$ for lambs from 2-yr-old ewes $(3.85 \pm 0.06 \mathrm{~kg})$ and heaviest for lambs from 4- through 8-yr-old ewes $(4.39 \pm 0.05,4.51 \pm 0.05$, $4.41 \pm 0.06,4.46 \pm 0.09$, and $4.37 \pm 0.13 \mathrm{~kg}$, respectively), which did not differ $(P \geq 0.15)$. Lambs from 3 -yr-old ewes weighed less at birth $(4.21 \pm 0.05)$ than lambs from 4-, 5-, and 6-yr-old ewes $(P \leq 0.05)$ but did not differ from lambs born to 7- or 8-yr-old ewes $(P \geq$ $0.10)$. When effects of litter size were excluded from the model, lambs born to 2-yr-old ewes were still somewhat lighter $(4.17 \pm 0.06)$ than lambs born to older ewes, but no differences were observed among 3- through 8-yr-old ewes $(P \geq 0.23)$, with mean birth weights that ranged from 4.42 to $4.53 \mathrm{~kg}$. This result indicates that among 2- through 8-yr-old ewes, lighter birth weights, and anticipated associated greater vulnerability to death losses, were detected only in progeny of 2-yr-old ewes.

When data were adjusted for effects of dam age class and lamb sex, but not for effects of litter size, lamb survival to $3 \mathrm{~d}$ of age and to weaning (Table 1) was greater $(P<0.001)$ for Rambouillet ewes $(0.94 \pm 0.01$ and $0.79 \pm$ 0.01 , respectively) than for Polypay ewes $(0.87 \pm 0.01$ and $0.67 \pm 0.02$, respectively). At $3 \mathrm{~d}$ of age, survival rates for RW-RA lambs did not differ $(P=0.21)$ from those for purebred Rambouillet lambs, but survival rates to weaning were greater $(P<0.001$ for RW-RA lambs $(0.86 \pm 0.01)$ than for purebred Rambouillet lambs $(0.72 \pm 0.02)$. Lamb survival to weaning differed among ewe age classes $(P=0.006)$, with lower lamb survival in progeny of 2-yr-old $(0.70 \pm 0.03)$ and 6- through 8 -yr-old ewes $(0.68 \pm 0.02)$ compared with 3 - through 5 -yr-old ewes (average of $0.76 \pm 0.01$ ). When effects of litter size were added to the model, lambs born as triplets and, especially, quadruplets had lower survival $(P \leq 0.008)$ to $3 \mathrm{~d}$ of age $(0.85 \pm 0.01$ and $0.54 \pm 0.09$, respectively) than lambs born as singles and twins $(0.96 \pm 0.02$ and $0.95 \pm$ 0.01 , respectively). By weaning, survival rates for lambs born as singles and twins $(0.91 \pm 0.03$ and $0.83 \pm 0.01$, respectively) tended to differ $(P=0.11)$ and were still greater $(P<0.001)$ than those of lambs born in litters of 3 or 4 lambs $(0.56 \pm 0.02$ and $0.49 \pm 0.09$, respectively). After removing effects of litter size, differences among lamb breed groups in survival to $3 \mathrm{~d}$ of age were not significant $(P \geq 0.60)$. At weaning, lamb breed groups did not differ in adjusted survival rates $(P \geq 0.12)$, but RW-RA crossbred lambs had somewhat greater survival rates $(0.82 \pm 0.05)$ than purebred Rambouillet $(0.71 \pm$ $0.05)$ and Polypay $(0.70 \pm 0.03)$ lambs. Net effects of lambing rate, litter size, and lamb survival, expressed as numbers of lambs weaned per ewe exposed, were greater $(P \leq 0.001)$ for Polypay $(1.54 \pm 0.04)$ and RW-RA lambs $(1.56 \pm 0.04)$ than for Rambouillet lambs $(1.24 \pm 0.04)$.

Actual weaning weights (adjusted only for effects of lamb sex and ewe age; Table 1) did not differ among progeny of the different mating types $(P>0.20)$. Anticipated negative effects of larger litters on lamb growth in Polypay ewes, compared with Rambouillet ewes, were, to some extent, compensated by earlier lambing dates for Polypay ewes and correspondingly older lamb ages at weaning (117 and $115 \mathrm{~d}$, respectively; $P<0.001$ ). Rambouillet ewes that produced RW-RA lambs also lambed earlier than Rambouillet ewes that produced purebred lambs, and their lambs were older at weaning (116 vs. $114 \mathrm{~d}$; $P<001)$. When effects of lamb type of birth and rearing and age at weaning were added to the model, adjusted weaning weights did not differ among mating types. Net effects of differences in lambing rate, litter size, lamb survival, and lamb growth on ewe productivity resulted in means for total weight of lamb weaned per ewe exposed of $38.3 \pm 1.4 \mathrm{~kg}$ for Rambouillet, $49.1 \pm 1.4 \mathrm{~kg}$ for Polypay, and $48.4 \pm 1.4 \mathrm{~kg}$ for RW-RA lambs (Table 1).

\section{Generation 2}

Cumulative Ewe Productivity. Ewes of the 3 breed types compared in Generation 2 differed in cu- 

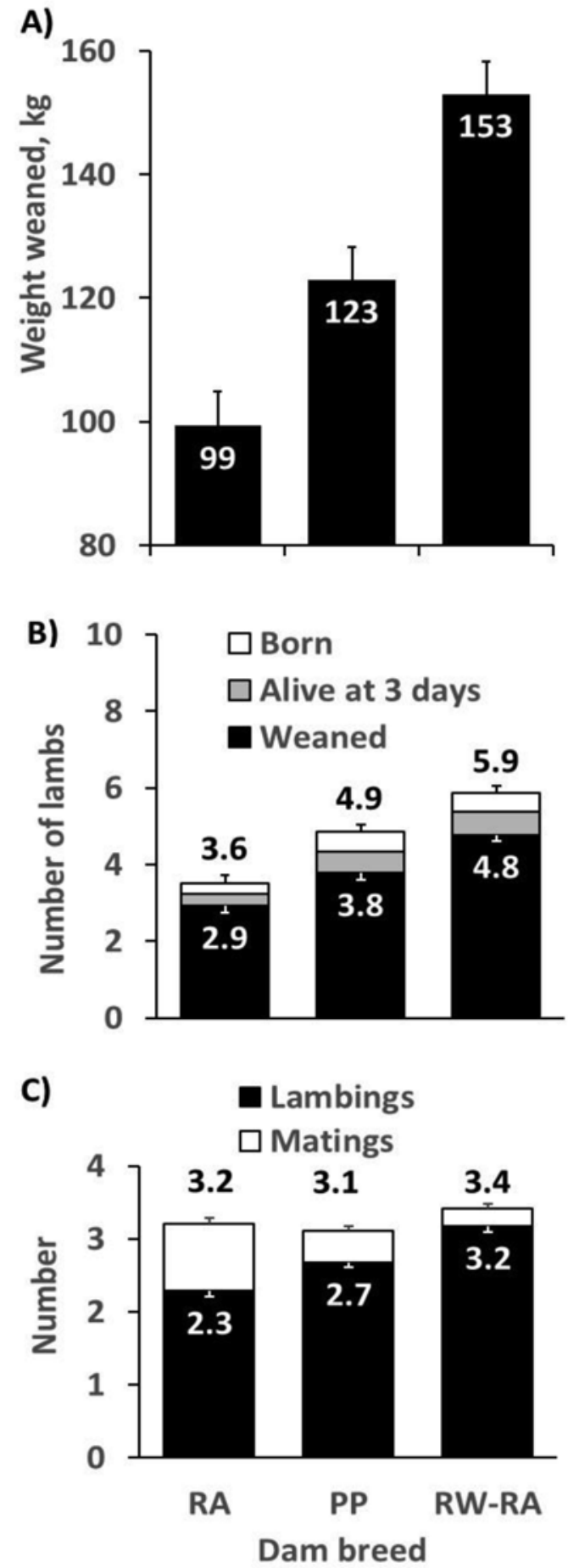

Figure 2. Weight of lamb weaned (A); numbers of lambs born, alive at $3 \mathrm{~d}$, and weaned (B); and numbers of matings and lambings (C) over 4 lambing opportunities beginning at $1 \mathrm{yr}$ of age for Rambouillet (RA), Polypay (PP), and Romanov-White Dorper $\times$ Rambouillet (RW-RA) ewes.

mulative ewe productivity $(P<0.001$; Fig. $2 \mathrm{~A})$. Over $4 \mathrm{yr}, \mathrm{RW}-\mathrm{RA}$ ewes weaned $24 \%$ more kilograms of lamb than Polypay ewes and 54\% more kilograms of lamb than Rambouillet ewes. Polypay ewes weaned $24 \%$ more kilograms of lamb than Rambouillet ewes. These differences corresponded to differences in cumulative numbers of lambs born and weaned $(P<$ 0.001 ; Fig. 2B) and mainly reflected greater prolifica-
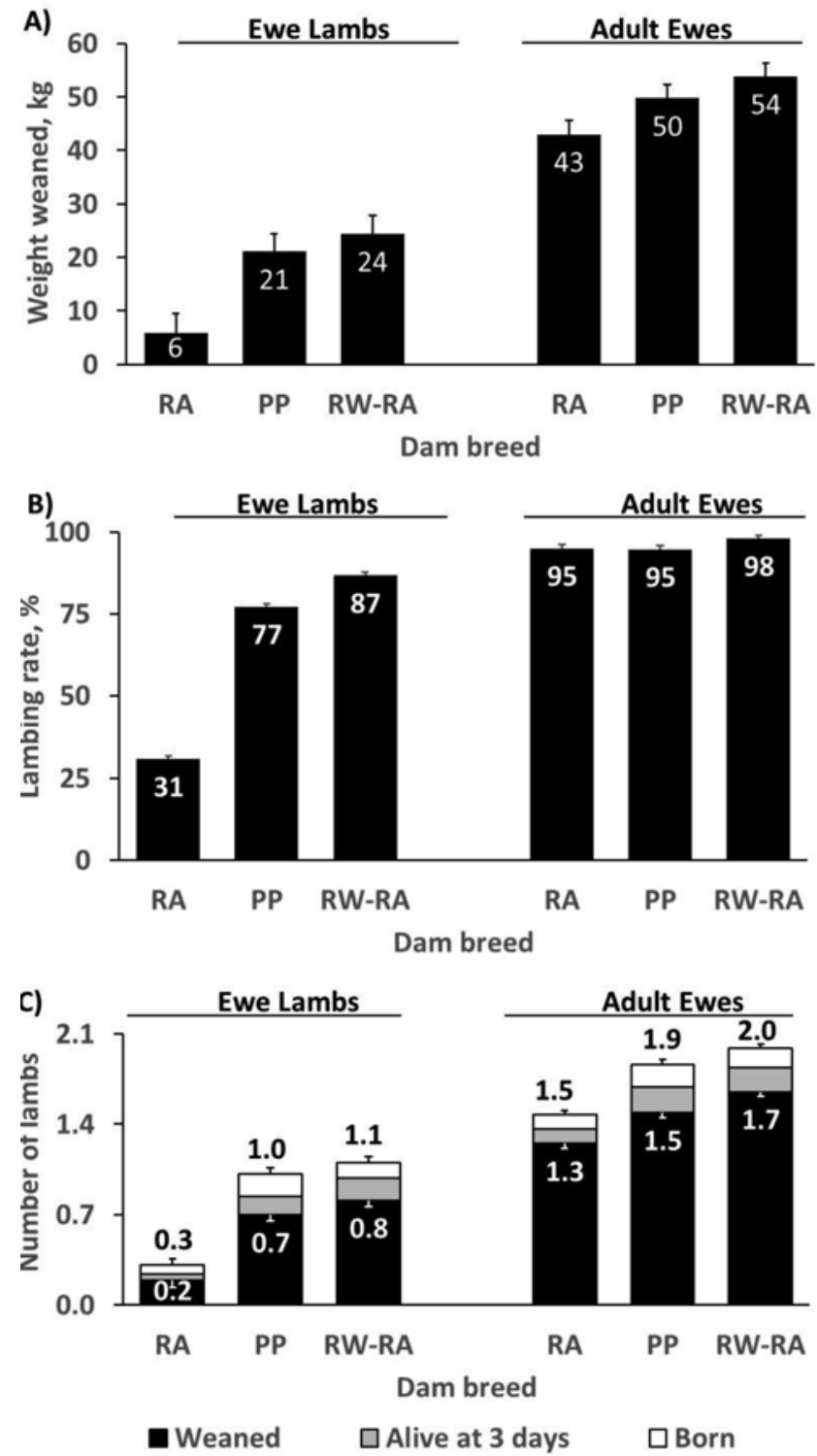

Figure 3. Weight of lamb weaned (A); ewe lambing rate (B); and numbers of lambs born, alive at $3 \mathrm{~d}$, and weaned (C) per ewe exposed in ewe lambs and adult (2- through 4-yr-old) Rambouillet (RA), Polypay (PP), and Romanov-White Dorper $\times$ Rambouillet $($ RW-RA) ewes.

cy of Polypay and RW-RA ewes but were accentuated by greater longevity for RW-RA ewes compared with Polypay ewes $(P=0.01)$ and greater lifetime lambing rates of RW-RA ewes compared with Polypay and, especially, Rambouillet ewes $(P<0.001$; Fig. $2 \mathrm{C})$.

Lambs Weaned per Ewe Exposed. Differences among ewe breed types in weight of lamb weaned per ewe exposed for ewe lambs and adult ewes (Fig. 3A) revealed that differences in ewe lamb performance had a major impact on cumulative ewe productivity. Lambing rates for Rambouillet ewe lambs averaged only $31 \%$, compared with $77 \%$ for Polypay ewe lambs and $87 \%$ for RW-RA ewe lambs (all $\pm 2 \%$; Fig. 3B), and with correspondingly fewer lambs born and weaned (Fig. 3C) and less weight of lamb weaned (Fig. 3A). Differences 

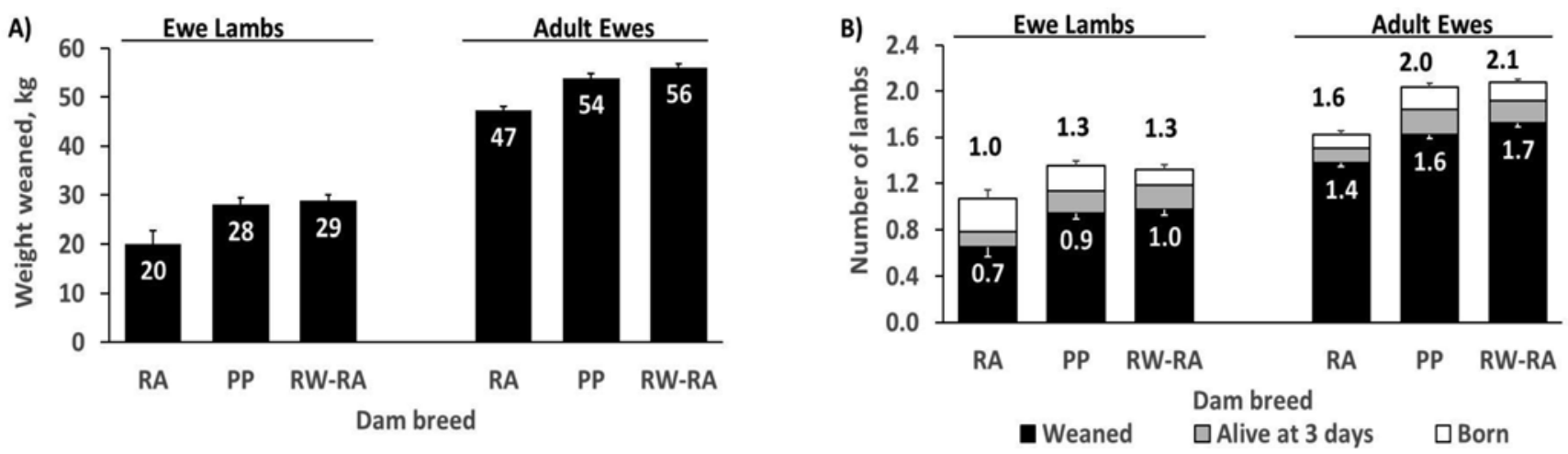

Figure 4. Weight of lamb weaned (A) and numbers of lambs born, alive at $3 \mathrm{~d}$, and weaned (B) per ewe lambing in ewe lambs and adult (2- through 4-yr-old) Rambouillet (RA), Polypay (PP), and Romanov-White Dorper $\times$ Rambouillet (RW-RA) ewes.

in productivity of adult ewes were smaller than differences observed in ewe lambs but were significant $(P<$ 0.001). Adult lambing rates (Fig. 3B) were similar for the 3 ewe breed types, but numbers of lambs weaned per ewe exposed (Fig. 3C) were 0.2 to 0.4 lambs greater for Polypay and RW-RA ewes than for Rambouillet ewes.

Lambs Weaned per Ewe Lambing. Weights (Fig. 4A) and numbers (Fig. 4B) of lambs weaned per ewe lambing were slightly greater for RW-RA adult ewes and ewe lambs than for Polypay adult ewes and ewe lambs but substantially less for Rambouillet ewes. Death losses at lambing were greater for progeny of Polypay and RW-RA ewes, but Polypay and RW-RA ewes still weaned 0.2 to 0.3 more lambs per ewe lambing than Rambouillet ewes as both adult ewes and ewe lambs (Fig. 4B). Ewe age effects on litter size in Generation 2 were large $(P<0001$; Fig. 1). Differences among breed types tended to be smaller in ewe lambs than in adult ewes $(P=0.08$ for ewe breed $\times$ dam age class interaction), but breed type $\times$ dam age interaction was not significant $(P=0.58)$ in adult ewes.

Lamb Growth and Survival. Random effects of maternal grandsire and dam on lamb survival were not significant $(P \geq 0.16)$, or converged to 0 , in mixed linear models and had to be excluded from binomial models of lamb survival to allow convergence of the solution vector, leaving the litter effect $(P<0.001)$ as the only random effect in these analyses.

Actual birth weights were heavier $(P<0.001)$ for lambs out of Rambouillet ewes than for lambs out of Polypay and RW-RA ewes (Table 2), which was consistent with their lower frequency of multiple births. Rambouillet ewe lambs produced almost all singles (Fig. 4B) but also had lower lamb survival to weaning $(62.1 \pm 7.7 \%)$ and did not significantly differ $(P \geq$ $0.10)$ from Polypay (72.2 $\pm 3.5 \%)$ and RW-RA (76.0 \pm $3.1 \%$ ) ewe lambs (Table 2). Lamb survival to weaning in adult ewes also did not differ $(P \geq 0.10)$ among ewe breed types, despite the greater prolificacy of Polypay and RW-RA ewes. Significant effects of litter size $(P<$
0.001 ) on lamb survival were observed in progeny of both ewe lambs and adult ewes. For ewe lambs, singles had greater $(P<0.01)$ survival rates $(75 \pm 3 \%)$ than twins $(60 \pm 5 \%)$, and for adult ewes, survival rates declined as litter sizes increased from 1 to 4 (94 \pm $1,89 \pm 1,60 \pm 3$, and $21 \pm 8 \%$, respectively). When lamb survival was adjusted for litter size (not shown), Rambouillet ewes had lower lamb survival compared with Polypay $(P=0.05)$ and RW-RA $(P=0.003)$ ewes.

Differences among ewe breed types in spring lamb weight were consistent with those observed for birth weights (Table 2). By weaning, differences in actual lamb weights among ewe breed types were small for ewe lambs, but in adult ewes, progeny of Rambouillet ewes were $1.5 \pm 0.5 \mathrm{~kg}$ heavier than progeny of Polypay ewes $(P=0.02)$ and $2.3 \pm 0.5 \mathrm{~kg}$ heavier than progeny of RW-RA ewes $(P<0.001)$. These differences were, in part, due to differences in prolificacy among ewe breed types but were also affected by differences in average weaning age (Table 2), which tended to compensate for observed differences in litter size. Lambs out of adult Rambouillet ewes were an average of $2.5 \mathrm{~d}$ younger at weaning than lambs out of Polypay and RW-RA ewes $(P<0.001)$, and lambs out of Rambouillet ewe lambs were an average of $8.7 \mathrm{~d}$ younger at weaning than lambs out of Polypay and RW-RA ewes $(P<0.001)$. If weaning weights were adjusted for effects of weaning age and number of lambs born and reared (Table 2), Polypay and RW-RA ewes produced slightly heavier lambs than Rambouillet ewes $(P=0.08)$.

Progeny of different ewe breed types did not differ in ultrasonic measurements of loin muscle area at weaning $(P=0.49)$. Lamb loin muscle area was strongly associated with weaning BW $(P<0.001)$, averaged $10.6 \mathrm{~cm}^{2}$, and was proportional to the $0.69 \pm 0.03$ power of BW. The coefficient of proportionality was consistent with the expected relationship between BW and a 2-dimensional cross-sectional measurement associated with body size. Ultrasonic back fat depth at weaning was slightly greater for progeny of RW-RA ewes $(P=0.07)$. This difference 
Table 2. Least squares means (SE) for performance of lambs produced by Rambouillet (RA), Polypay (PP), and Romanov-White Dorper $\times$ Rambouillet (RW-RA) ewe lambs and adult (2- through 4-yr-old) ewes

\begin{tabular}{|c|c|c|c|c|c|c|c|c|}
\hline \multirow[b]{2}{*}{ Measurement ${ }^{1}$} & \multirow{2}{*}{$\begin{array}{c}\text { No. of } \\
\text { observations }\end{array}$} & \multirow{2}{*}{$\begin{array}{l}\text { Significance } \\
\text { levels }\end{array}$} & \multicolumn{3}{|c|}{ Ewe lambs } & \multicolumn{3}{|c|}{ Adult ewes } \\
\hline & & & RA & $\mathrm{PP}$ & RW-RA & RA & $\mathrm{PP}$ & RW-RA \\
\hline$\overline{\mathrm{BWT}^{3}}$ & 3,170 & $<0.001$ and 0.26 & $5.23(0.14)$ & $4.52(0.08)$ & $4.40(0.08)$ & $5.89(0.06)$ & $4.93(0.06)$ & $4.83(0.06)$ \\
\hline SURV $^{3}$ & 3,232 & 0.16 and 0.11 & $62.1(7.7)$ & $72.2(3.5)$ & $76.0(3.1)$ & $86.6(1.5)$ & $81.8(1.5)$ & $85.3(1.2)$ \\
\hline SPWT $^{3}$ & 2,721 & $<0.001$ and 0.09 & $11.5(0.5)$ & $10.4(0.3)$ & $10.8(0.2)$ & $14.2(0.2)$ & $12.7(0.2)$ & $12.5(0.2)$ \\
\hline $\mathrm{WWT}^{3}$ & 2,549 & 0.05 and 0.33 & $31.4(1.3)$ & $30.5(0.5)$ & $30.7(0.5)$ & $35.3(0.3)$ & $33.8(0.3)$ & $33.0(0.3)$ \\
\hline WAGE $^{3}$ & 2,549 & $<0.001$ and $<0.001$ & $101.7(1.2)$ & $108.4(0.5)$ & $112.4(0.5)$ & $105.6(0.3)$ & $108.2(0.3)$ & $108.0(0.3)$ \\
\hline Adj. $W_{W T}^{4}$ & 2,549 & 0.08 and 0.86 & $27.0(0.9)$ & $28.3(0.4)$ & $27.8(0.4)$ & $32.6(0.3)$ & $33.7(0.3)$ & $33.5(0.3)$ \\
\hline
\end{tabular}

${ }^{1}$ BWT = birth weight $(\mathrm{kg})$; SURV = lambs weaned/lambs born (\%); SPWT = spring weight $(\mathrm{kg})$; WWT = weaning weight $(\mathrm{kg})$; WAGE = weaning age $(\mathrm{d})$.

${ }^{2}$ Significance $(P<)$ of ewe breed type and ewe breed type $\times$ ewe age class effects, respectively.

${ }^{3}$ Adjusted for effects of ewe age and lamb sex.

${ }^{4}$ Adjusted (Adj.) for effects of ewe age, lamb sex, type of birth and rearing, and lamb age.

was accentuated $(P=0.001)$ by adjustment for scanning BW; resulting means were 2.43, 2.41, and $2.67( \pm 0.05)$ $\mathrm{mm}$ for progeny of Rambouillet, Polypay, and RW-RA ewes, respectively. Back fat depth at weaning was proportional to the $0.81 \pm 0.06$ power of $\mathrm{BW}(P<0.001)$.

Differences among Sire Breed Types. The breed type of the terminal sire had only small effects on lamb performance and ewe productivity (Table 3). Ewe lambs mated to Columbia sires had somewhat greater lambing rates than ewe lambs mated to rams of other breed types $(P=0.05)$, but this difference was not detected in adult ewes. Sire breed types did not differ in actual (i.e., unadjusted) BW at birth $(P=0.09)$, in the spring $(P=$ 0.47; not shown), or at weaning $(P=0.28)$. When birth weights were adjusted for litter size, Suffolk-sired lambs were heavier at birth $(P=0.01)$ than progeny of other sire breed types. Differences among sire breed types were not observed for adjusted lamb weights in spring ( $P=0.68$; not shown) or at weaning, although progeny of Columbia sires had somewhat lower adjusted weaning weights $(P=0.12)$. Suffolk-sired lambs had somewhat larger loin muscle areas at weaning $(P=0.18)$, but differences were reduced $(P=0.22)$ by adjustment for weaning BW. Sire breed types did not differ for any other measured variables ( $P \geq 0.44$; not shown), including, especially, measures of cumulative ewe productivity $(P \geq 0.74$; not shown). Sire breed type $\times$ ewe breed type interactions were not observed $(P \geq 0.29)$.

\section{DISCUSSION}

Major advantages in ewe lamb productivity and modest advantages in many components of adult ewe productivity resulted in much greater cumulative lamb production for Polypay and RW-RA crossbred ewes compared with Rambouillet ewes. Based on a 2015 average price of US\$4.22/ $\mathrm{kg}$ for feeder lambs (Livestock Marketing Information Center, 2016), gross receipts from sales of feeder lambs through 4 lambings for RW-
RA and Polypay ewes were $\$ 225$ and $\$ 100$ greater, respectively, than receipts from Rambouillet ewes, and gross receipts from lamb production were $\$ 125$ greater for RW-RA ewes than for Polypay ewes. Many range sheep producers do not breed ewe lambs. However, even in adult (2- to 4-yr-old) ewes (Fig. 3), RW-RA ewes weaned $8 \%$ more kilograms of lamb per ewe exposed than Polypay ewes and 25\% more kilograms of lamb per ewe exposed than Rambouillet ewes. Adult Polypay ewes weaned 16\% more kilograms of lamb per ewe exposed than adult Rambouillet ewes. Use of Polypay and RW-RA crossbred and composite ewes was, therefore, still associated with large increases in the weight and numbers of lamb weaned by adult ewes.

Advantages of RW-RA ewes over Polypay and Rambouillet ewes and Polypay ewes over Rambouillet ewes included both additive breed effects and effects of differences in realized levels of heterosis among ewe breed types. The RW-RA ewes were expected to express the full effects of heterosis in the crossbred ewes, whereas Rambouillet ewes would not have benefited from effects of heterosis. The Polypay is a stabilized composite breed derived by crossing 4 breeds (Rambouillet, Targhee, Dorset, and Finnsheep) and initially was expected to express $75 \%$ of maximum heterosis. However, expression of heterosis declines when newly created composite breeds accumulate inbreeding (Dickerson, 1973; Boylan, 1985; Young and Dickerson, 1985) and may also have been less than expected because the Rambouillet and Targhee founder breeds were related (Terrill, 1947). Based on this founder relationship and an average inbreeding coefficient of approximately 0.10 in USSES Polypay sheep (Zhang et al., 2013), the current level of realized heterosis in USSES Polypay ewes was hypothesized to be approximately $65 \%$ of maximum. Generation 2 lambs were sired by breed types that were unrelated to the ewes, and all lambs therefore benefited from full effects of heterosis. Additive breed effects and effects of heterosis cannot be separated in this study, but 
Table 3. Least squares means and SE for selected traits for Generation 2 progeny of Suffolk (SU), Columbia $(\mathrm{CO})$, Suffolk $\times$ Columbia $(\mathrm{SC})$, and Columbia $\times$ Suffolk $(\mathrm{CS})$ sires mated to purebred Rambouillet, purebred Polypay, and Romanov-White Dorper $\times$ Rambouillet ewe lambs and adult ewes

\begin{tabular}{|c|c|c|c|c|c|c|c|}
\hline \multirow[b]{2}{*}{ Measurement } & \multirow{2}{*}{$\begin{array}{c}\text { Significance } \\
\text { levels }^{1}\end{array}$} & \multirow[b]{2}{*}{ Ewe age } & \multicolumn{4}{|c|}{ Sire breed type } & \multirow[b]{2}{*}{ SE } \\
\hline & & & $\mathrm{SU}$ & $\mathrm{CO}$ & $\mathrm{SC}$ & $\mathrm{CS}$ & \\
\hline \multirow[t]{2}{*}{ Lambing rate, $\%$} & 0.25 and 0.08 & Ewe lambs & 62 & 71 & 65 & 62 & 2 \\
\hline & & Adult ewes & 97 & 95 & 96 & 95 & 1 \\
\hline \multirow[t]{2}{*}{ Birth weight, ${ }^{2} \mathrm{~kg}$} & 0.09 and 0.11 & Ewe lambs & 4.92 & 4.67 & 4.55 & 4.71 & 0.10 \\
\hline & & Adult ewes & 5.27 & 5.16 & 5.22 & 5.20 & 0.06 \\
\hline \multirow[t]{2}{*}{ Adjusted birth weight, ${ }^{3} \mathrm{~kg}$} & 0.01 and 0.12 & Ewe lambs & 4.69 & 4.38 & 4.38 & 4.40 & 0.08 \\
\hline & & Adult ewes & 4.92 & 4.81 & 4.82 & 4.82 & 0.06 \\
\hline \multirow[t]{2}{*}{ Weaning rate, ${ }^{2} \%$} & 0.91 and 0.26 & Ewe lambs & 75 & 70 & 68 & 69 & 5 \\
\hline & & Adult ewes & 82 & 84 & 86 & 87 & 2 \\
\hline \multirow[t]{2}{*}{ Adjusted weaning rate, ${ }^{3} \%$} & 0.93 and 0.25 & Ewe lambs & 73 & 67 & 66 & 66 & 5 \\
\hline & & Adult ewes & 69 & 71 & 76 & 74 & 3 \\
\hline \multirow[t]{2}{*}{ Weaning weight, ${ }^{2} \mathrm{~kg}$} & 0.28 and 0.24 & Ewe lambs & 30.9 & 31.0 & 31.0 & 30.3 & 0.8 \\
\hline & & Adult ewes & 34.3 & 32.9 & 34.6 & 34.2 & 0.4 \\
\hline \multirow[t]{2}{*}{ Adjusted weaning weight, ${ }^{4} \mathrm{~kg}$} & 0.12 and 0.16 & Ewe lambs & 28.0 & 27.5 & 28.2 & 27.1 & 0.6 \\
\hline & & Adult ewes & 33.7 & 32.5 & 33.3 & 33.5 & 0.3 \\
\hline Weaning LMA, ${ }^{2,5} \mathrm{~cm}^{2}$ & 0.18 & Adult ewes & 11.1 & 10.7 & 10.8 & 10.8 & 0.1 \\
\hline Weight-adjusted weaning LMA, $\mathrm{cm}^{2}$ & 0.22 & Adult ewes & 10.7 & 10.6 & 10.4 & 10.6 & 0.1 \\
\hline
\end{tabular}

${ }^{1}$ Significance $(P<)$ of sire breed type and sire breed type $\times$ ewe age class effects, respectively

${ }^{2}$ Adjusted only for effects of ewe age and lamb sex.

${ }^{3}$ Also adjusted for effects of litter size.

${ }^{4}$ Also adjusted for effects of type of birth and rearing and lamb age class at weighing.

${ }^{5} \mathrm{LMA}=$ loin muscle area.

the ewe breed types that were compared represented those available to the sheep industry. Realized performance levels for different ewe breed types, therefore, provided an appropriate basis for comparison, but their use in breeding programs must also address complexities associated with the creation of composite breeds or production of crossbred replacement ewes.

Differences among ewe breed types in weight of lamb weaned per ewe exposed in the current study were proportionately greater than the $18 \%$ advantage for crossbred ewes reported by Nitter (1978). Nitter (1978) also reported an average advantage of $8.7 \%$ in fertility for crossbred ewes, but high average lambing rates for adult Rambouillet ewes in the current study limited expression of heterosis for lambing rates, in accord with observations by Song and Dinkel (1974) on expression of heterosis in binomial traits. However, small advantages in lambing rates for RW-RA adult ewes (Fig. 3B) were consistent with their greater heterozygosity. In contrast, lambing rates for Rambouillet ewe lambs, compared with Polypay and RW-RA ewe lambs, were less than expected from differences in heterosis and presumably reflected breed differences in maturing rate and age at puberty. Differences in litter size (Fig. 4B) between Polypay and RW-RA females were small and may have arisen from differences in heterosis and modest favorable additive effects of the Romanov, compared with the Finnsheep (Thomas, 2010). However, advantages in litter size for Polypay and RW-RA ewes, compared with Rambouillet ewes, were much larger than those expected from the estimated heterosis effect on litter size of $3.2 \%$ reported by Nitter (1978) and presumably reflected contributions of prolific Finnsheep and Romanov breeds to Polypay and RW-RA ewes, respectively.

Differences in longevity (cumulative numbers of matings, with a maximum of 4; Fig. 2C) contributed to the superiority of RW-RA ewes in cumulative ewe productivity. Few studies have reported effects of heterosis on ewe longevity. However, Boylan (1985) reported heterosis of $13.4 \%$ for age at culling for crosses involving the Finnsheep, Targhee, and Suffolk breeds. The greater longevity for RW-RA ewes, compared with Polypay and Rambouillet ewes, was, therefore, consistent with their greater heterozygosity but could also reflect founder effects of the Romanov and White Dorper in RW-RA ewes, compared with founder effects of the Dorset and Finnsheep in the Polypay. The poorer longevity of Polypay ewes was not consistent with expected effects of heterosis and presumably arose from negative founder effects.

Lamb survival in progeny of ewe lambs (Table 2) favored crossbred ewe lambs, but differences were larger than the estimate of $2.7 \%$ for maternal heterosis for lamb survival from Nitter (1978). In contrast, differences among ewe breed types in survival of progeny of adult ewes were a more complicated function of breed 
effects, heterosis, and average prolificacy. Polypay and RW-RA adult ewes produced similar numbers of lambs, but progeny of RW-RA ewes had slightly greater survival to weaning than progeny of Polypay ewes and the difference exceeded that anticipated from differences in heterosis between these 2 ewe breed types. However, greater survival of lambs from adult Rambouillet ewes presumably was driven largely by their smaller litters.

Purebred and crossbred sires generally did not significantly differ for measures of ewe productivity or lamb performance. Lambing rates for crossbred rams were slightly less than those for purebred rams in both ewe lambs (63.5 vs. $66.5 \%)$ and adult ewes (95.5 vs. $96.0 \%$ ), and differences between crossbred and purebred rams were small $(P \geq 0.74)$ for measures of ewe productivity. These results were consistent with results reviewed by Leymaster (1987) indicating that positive effects of heterosis for lambing rate in crossbred rams were observed in spring matings but rarely reported in matings that occurred during the traditional autumn breeding season. However, testing of effects of heterosis in crossbred rams is challenging. Optimal experimental designs require relatively large numbers of mating pens, ideally with relatively large numbers of ewes and at most small numbers of rams of a single breed type in each pen. Such a design provides both an adequate challenge to critically assess mating capacity and adequate replication to allow testing of differences in performance. However, these designs are difficult to implement because of the large numbers of ewes and mating pens required. Definitive comparisons of mating performance by different ram breed types are correspondingly rare.

In terms of lamb performance, lambs sired by crossbred rams were generally intermediate in BW to lambs sired by purebred rams. Suffolk-sired lambs had somewhat greater adjusted weights at birth and weaning than Columbia-sired lambs. The difference in adjusted weaning weight between these 2 sire breeds of $1.2 \pm 0.4 \mathrm{~kg}$ in progeny of adult ewes in the current study was similar to the difference of $1.5 \pm 0.5 \mathrm{~kg}$ reported by Leeds et al. (2012).

\section{Conclusions}

In a rangeland production system, Polypay and RW-RA ewes benefitted from additive breed effects and heterosis favoring greater ewe lamb productivity and numbers of lambs born per ewe lambing. As expected, death losses were greater and lamb growth rates were less for lambs born in larger litters. Nonetheless, combined effects of additive breed differences and heterosis allowed Polypay and RW-RA ewes to wean more weight and greater numbers of lambs than Rambouillet ewes in a terminal-sire crossbreeding system. The RW-
RA ewes also weaned more weight and greater numbers of lambs than Polypay ewes, suggesting potential for this crossbred ewe in rangeland production.

\section{LITERATURE CITED}

Alemseged, Y., and R. B. Hacker. 2014. Introduction of Dorper sheep into Australian rangelands: Implications for production and natural resource management. Rangeland J. 36:85-90. doi:10.1071/ RJ13034

Boylan, W. J. 1985. Crossbreeding for fecundity. In: R. B. Land and G. E. Bradford, editors, Genetics of reproduction in sheep Butterworths, London, UK. p. 19-24. doi:10.1016/B978-0-40700302-6.50005-2

Bradford, E. 2003. Breeding and genetics chapter. In: SID sheep production handbook. 2002 ed. American Sheep Industry Association, Centennial, CO. p. 1-80.

Dickerson, G. E. 1973. Inbreeding and heterosis in animals. In: W. R. Harvey, editor, Proc. Anim. Breed. Genet. Symp. In Honor of Dr. J. L. Lush. Amer. Soc. Anim. Sci., Champaign, IL. p. 54-77.

Hulet, C. V., S. K. Ercanbrack, and A. D. Knight. 1984. Development of the Polypay breed. J. Anim. Sci. 58:15-24. doi:10.2527/ jas1984.58115x

Leeds, T. D., M. R. Mousel, D. R. Notter, H. N. Zerby, C. A. Moffet, and G. S. Lewis. 2008. B-mode, real-time ultrasound for estimating carcass measures in live sheep: Accuracy of ultrasound measures and their relationships with carcass yield and value. J. Anim. Sci. 86:3203-3214. doi:10.2527/jas.2007-0836

Leeds, T. D., D. R. Notter, K. A. Leymaster, M. R. Mousel, and G. S. Lewis. 2012. Evaluation of Columbia, USMARC-Composite, Suffolk, and Texel rams as terminal sires in an extensive rangeland production system: I. Ewe productivity and crossbred lamb survival and preweaning growth. J. Anim. Sci. 90:2931-2940. doi:10.2527/jas.2011-4640

Leymaster, K. A. 1987. The crossbred sire: Experimental results for sheep. J. Anim. Sci. 65:110-116. doi:10.2527/jas1987.651110x

Livestock Marketing Information Center. 2016. LMIC offers sheep \& lamb analysis. Sheep Ind. News 20(5):7-10.

Lupton, C. J. 2008. Impacts of animal science research on United States sheep production and predictions for the future. J. Anim. Sci. 86:3252-3274. doi:10.2527/jas.2008-1148

Nitter, G. 1978. Breed utilization for meat production in sheep. Anim. Breed. Abstr. 46:131-143.

Notter, D. R. 1999. Potential for hair sheep in the United States. J. Anim. Sci. 77(E-Suppl.):1-8.

Notter, D. R., M. R. Mousel, T. D. Leeds, J. B. Taylor, D. P. Kirschten, and G. S. Lewis. 2012. Evaluation of Columbia, USMARCComposite, Suffolk, and Texel rams as terminal sires in an extensive rangeland production system: II. Postweaning growth and ultrasonic measures of composition. J. Anim. Sci. 90:2941-2952. doi:10.2527/jas.2011-4641

Snowder, G. D., and N. M. Fogarty. 2009. Composite trait selection to improve reproduction and ewe productivity: A review. Anim. Prod. Sci. 49:9-16. doi:10.1071/EA08184

Song, H., and C. A. Dinkel. 1974. Alternative methods of utilizing heterosis estimates. J. Anim. Sci. 39:966. (Abstr.)

Terrill, C. E. 1947. Breed crosses used in the development of Targhee sheep. J. Anim. Sci. 6:83-92. doi:10.2527/jas1947.6183

Thomas, D. L. 2010. Performance and utilization of Northern European short-tailed breeds of sheep and their crosses in North America: A review. Animal 4:1283-1296. doi:10.1017/S1751731110000856 
Young, L. D., and G. E. Dickerson. 1985. Evaluation and utilization of Finn sheep. In: R. B. Land and G. E. Bradford, editors, Genetics of reproduction in sheep. Butterworths, London, UK. p. 25-38. doi:10.1016/B978-0-407-00302-6.50006-4
Zhang, L., M. R. Mousel, X. Wu, J. J. Michal, X. Zhou, B. Ding, M. V. Dodson, N. K. El-Halawany, G. S. Lewis, and Z. Jiang. 2013. Genome-wide genetic diversity and differentially selected regions among Suffolk, Rambouillet, Columbia, Polypay, and Targhee sheep. PLoS One 8(6):e65942. doi:10.1371/journal. pone.0065942 